Pesq. Vet. Bras. 35(Supl.1):15-20, dezembro 2015 DOI: $10.1590 / \mathrm{S} 0100-736 \mathrm{X} 2015001300004$

\title{
Toxicity and oxidative stress of canine mesenchymal stromal cells from adipose tissue in different culture passages ${ }^{1}$
}

\author{
Arícia Gomes Sprada ${ }^{2 *}$, Matheus Pippi da Rosa², Alencar Kolinski Machado ${ }^{3}$, Ney \\ Luis Pippi ${ }^{2}$, Paulo Bayard ${ }^{2}$ and Ivana Beatrice Mânica da Cruz ${ }^{3}$
}

\begin{abstract}
Sprada A.G., Rosa M.P., Machado A.K., Pippi N.L., Bayard P. \& Cruz I.B.M. 2015. Toxicity and oxidative stress of canine mesenchymal stromal cells from adipose tissue in different culture passages. Pesquisa veterinária Brasileira 35(Supl.1):15-20. Laboratório de Cirurgia Experimental, Pós-Graduação em Medicina Veterinária, Universidade Federal de Santa Maria, Avenida Roraima 1000, Camobi, Santa Maria, RS 97105-900, Brazil. E-mail: aricia.sprada@hotmail.com

Stem cells in regenerative therapy have received attention from researchers in recent decades. The culture of these cells allows studies about their behavior and metabolism. Thus, cell culture is the basis for cell therapy and tissue engineering researches. A major concern regarding the use of cultivated stem cell in human or veterinary clinical routine is the risk of carcinogenesis. Cellular activities require a balanced redox state. However, when there is an imbalance in this state, oxidative stress occurs. Oxidative stress contributes to cytotoxicity, which may result in cell death or genomic alterations, favoring the development of cancer cells. The aim of this study was to determine whether there are differences in the behavior of cultured mesenchymal stem cells from canine adipose tissue according to its site of collection (omentum and subcutaneous) evaluating the rate of proliferation, viability, level of oxidative stress and cytotoxicity over six passages. For this experiment, two samples of adipose tissue from subcutaneous and omentum where taken from a female dog corpse, 13 years old, Pitbull. The results showed greater levels of oxidative stress in the first and last passages of both groups, favoring cytotoxicity and cell death.
\end{abstract}

INDEX TERMS: Stem cell, culture, passage, cell viability, free radicals.

RESUMO.- [Toxicidade e estresse oxidativo das células mesenquimais estromais do tecido adiposo de cão em diferentes passagens de cultura.] 0 uso de células-tronco como terapia regenerativa tem recebido atenção de pesquisadores nas últimas décadas. A possibilidade de cultivá-las permite o estudo de seu comportamento e metabolismo. Assim, o cultivo celular representa a base para pesquisas de terapia celular e engenharia de tecidos. Uma das principais preocupações relativa ao uso de células-tronco cultivas na rotina clínica humana ou veterinária é a reprogramação dessas células em tumores benignos ou

\footnotetext{
${ }^{1}$ Received on April 13, 2015.

Accepted for publication on November 29, 2015.

${ }^{2}$ Programa de Pós-Graduação em Medicina Veterinária, área de concentração Clínica e Cirurgia, Centro de Ciências Rurais (CCR), Universidade Federal de Santa Maria (UFSM), Camobi, Santa Maria, RS 97105-900, Brazil. *Corresponding author: aricia.sprada@hotmail.com

${ }^{3}$ Programa de Pós-Graduação em Farmacologia, CCS-UFSM, Camobi, Santa Maria, RS 97105-900, Brasil.
}

malignos. As atividades celulares necessitam de um estado redox balanceado e quando há algum desequilíbrio nessas reações ocorre o estresse oxidativo. 0 quadro de estresse oxidativo contribui pra a citotoxicidade podendo resultar em morte celular e até mesmo em alterações genômicas e ocorrência de células cancerígenas. 0 objetivo deste trabalho foi verificar se há diferenças no comportamento de células-tronco mesenquimais estromais de tecido adiposo de cão de acordo com o seu tecido de coleta (omento e subcutâneo) avaliando o cultivo dessas células quanto a sua taxa de proliferação, viabilidade, estresse oxidativo e citotoxicidade ao longo de seis passagens. Para a execução deste experimento foram utilizadas duas amostras de tecido adiposo coletas do subcutâneo e omento do cadáver de um cão, fêmea, 13 anos de idade, da raça Pitbull. 0 cadáver era oriundo do Hospital Veterinário Universitário e sofreu eutanásia devido a complicações no seu quadro de cardiomiopatia. As duas amostras foram encaminhadas para o isolamento e cultura celular. Os resultados mostraram que a primeira e última passagem em ambos os grupos são as 
passagens mais submetidas ao estresse oxidativo ficando mais sujeitas à citotoxicidade.

TERMOS DE INDEXAÇÃO: Células-tronco, cultura, passagem, viabilidade celular, radicais livres.

\section{INTRODUCTION}

Stem cells (SC) are investigated since 1960 when Ernest A. Mac Culloch and James E. Till observed for the first time a certain undifferentiated bone marrow cell with the ability of self-renewal, self-generation and differentiation (Bonventre \& Yang et al. 2011). Since then, stem cells are considered a promise in the field of regenerative medicine and many studies have been developed for their better understanding (Fortier 2005). SC can be classified according to their origin: embryonic stem cells (ESC) are derived from embryos, more specifically in the blastocyst stage, and are able to differentiate themselves in all cell types; adult stem cells (ASC) are found, virtually, in any tissue, however their differentiation is limited to their germ layer origin (Tuan et al. 2003).

The first studies with embryonic stem cells (EST) were performed in mice in 1981. Subsequently in 1998 a study with EST derived from a human embryo was reported and it raised ethical and religious issues (Thomson 1998). Due to the controversy involved in the use of EST, adult stem cells became an alternative to new research in cell therapy (Williams 2007). Within literature, ASC isolation has been reported in bone marrow, adipose tissue, kidney, liver, tendon, synovial membrane, amniotic fluid, placenta, umbilical cord and dental pulp (Fortier 2005, Fadel et al. 2011). Among those, adipose tissue was shown to be a reliable and easily accessible source (Kern et al. 2006).

The expansion and cultivation of adult and embryonic stem cells allowed significant progress in the fields of regenerative medicine and tissue engineering, as well as in the pharmaceutical industry, in the development and evaluation of new drugs (Sareen 2009). Nevertheless, particular issues must be clarified before cultivated stem cells are widely used in clinical routine. The major concern regarding the cultivation of adult and embryonic stem cells is the development of chromosomal abnormalities, possibly leading to loss of function or potentiating the risk of carcinogenesis. These complications may prevent the therapeutic application of stem cells and should be investigated carefully (Furlani 2009, Sareen 2009).

One of the main factors that could be related to chromosomal instability in cultured cells is oxidative stress (OS) (Riley et al. 2008). Some free radicals are physiologically generated during cellular metabolism and often play an important role as messengers and regulators in proliferation, differentiation and apoptosis processes (Dröge 2002, Halliwell 2007). However, when free radical and reactive oxygen species are not regulated by a cascade of antioxidants systems, oxidative stress occurs. OS is detrimental to cells causing ruptures of membranes, protein degradation and DNA damage, which may lead to cell death or genomic abnormality, also favoring the occurrence of carcinogenesis (Pujalté et al. 2011).
The aim of this study was to evaluate the rate of proliferation, viability, oxidative stress and damage of mesenchymal stem cell from canine subcutaneous and omental adipose tissue over six passages.

\section{MATERIALS AND METHODS}

For this study was used the corpse of a 13-year-old female Pitbull from the Veterinary Hospital routine. The patient was euthanized due to complications of dilated cardiomyopathy and its death had no relation with this experiment. The owners donated the corpse for research. At about 30 minutes after euthanasia, the samples of adipose tissue were removed from subcutaneous (SUB) and omentum (OM). For the transport of the material previous to cells' isolation, the adipose tissue was separately in falcon tubes containing Hanks' balanced solution (1\% streptomycin, 1\% amphoteri$\operatorname{cin} \mathrm{B})$ to avoid contamination.

Inside the laminar flow, the fragments of adipose tissue from SUB and OM were transferred to two Petri plates. Making use of two scalpel blades each fat was sectioned into small fragments. These fragments were placed separately in $50 \mathrm{~mL}$ falcon tube along with $2 \mathrm{mg} / \mathrm{mL}$ collagenase type I in order to promote tissue degradation. The tubes remained in water bath at a temperature of $37^{\circ} \mathrm{C}$ for 40 minutes being manually shaken every 10 minutes. After this process, the tubes were referred to laminar flow again and complete DMEN medium (1\% penicillin, $1 \%$ amphotericin $\mathrm{B}$, $10 \%$ fetal bovine serum) was added to the solution at a ratio of two parts of medium to one part of collagenase to neutralize the collagenase, given its citotoxicity. The tubes were centrifuged at $600 \mathrm{G}$ for ten minutes. The supernatant was discarded and a new complete medium was added to the cells pellet. The latter solution was transferred to a cell culture flask identified with SUB and $\mathrm{OM}$ according to the tissue origin. The flasks were maintained in a $\mathrm{CO}_{2}$ incubator at $37^{\circ}$ and $5 \%$ concentration of carbon dioxide. The first medium exchange was performed every 24 hours, the following exchanges were realized at every 72 hours. The cells were submitted to six passages and each passage length varied according to the cell growth. When the flask reached $90 \%$ of cell confluence, a new passage was made.

Each passage was performed after complete removal of the medium by adding $2.5 \mathrm{mg} / \mathrm{mL}$ trypsin in the flask to remove cells from the plastic. The bottles were subsequently placed in the $\mathrm{CO}_{2}$ incubator for five minutes. At the end of this process a new complete medium was placed to inactivate trypsin. The solution from the bottle was then transferred to falcon tubes and centrifuged for five minutes at a speed of $1900 \mathrm{rpm}$. The precipitate obtained was allocated in the cell culture flask along with complete medium. For every passage the rates of viability, proliferation, cytotoxicity and oxidative stress were assessed.

The viability and proliferation rates were estimated by counting viable and non-viable cells in a Neubauer chamber. For this $20 \mu \mathrm{l}$ of the cell solution was placed in a $1 \mathrm{~mL}$ micro tube and it was added $20 \mu \mathrm{l}$ of trypan blue dye at $0.4 \%$. Cells were counted in a Neubauer chamber and the estimation was performed using the following formula: Number of cell per $\mathrm{mL}=$ Number of cells counted $\mathrm{x}$ dilution coefficient $\mathrm{x} 10^{4}$. The number of cell counted was divided by the number of quadrants counted. The dilution coefficient was defined by the rate of cell suspension and the amont of dye (i.e., 1:1) which results in two.

Cytotoxicity was measured by means of the DNA fragmentation by fluorimetric Picogreen analyses. A small amount of DNA picogreen was added to the samples, which remained at rest in the dark for five minutes. Soon after, the free-DNA concentration was measured by the fluorometer excited at $485 \mathrm{~nm}$ wavelength and fluorescence intensity at $520 \mathrm{~nm}$. Samples were prepared in quadruplicate. 
The production of oxidative stress was evaluated using a non-fluorescent cell-permeating compound 2-70-dichlorofluorescein diacetate (DCFH-DA assay). DCFH-DA is hydrolysed by intracellular esterases to dichlorofluorescein (DCFH), which is trapped within the cell. This non-fluorescent molecule is then oxidized to fluorescent dichlorofluorescein (DCF) by cellular oxidants. The samples of each culture passage were treated with DCFH-DA for 60 minutes at $37^{\circ} \mathrm{C}$. The fluorescence was measured at en excitation wavelength of $485 \mathrm{~nm}$ and emission of $520 \mathrm{~nm}$. The calibration curve was performed with standard DCF and the level of reactive oxide species production was calculated as nmol DCF formed/mg protein.

The lipid peroxidation was determined by measuring thiobarbituric acid reactive species (TBARS). The cell solutions were centrifuged for 10 minutes at 2000rpm, the supernatant was discarded and saline solution $(0.9 \% \mathrm{NaCl})$ was added, followed by two additional centrifugations at 2000rpm for 10 minutes. After that, the supernatant was discarded and $100 \mathrm{ml}$ Butylated hydroxytoluene (BHT $100 \mathrm{mM}$ ) and $500 \mu$ l of trichloroacetic acid (TCA $20 \%$ ) were added to the sample, followed by final centrifugation at 2000rpm for 5 minutes. Immediately after centrifugation, two samples with $900 \mu \mathrm{l}$ of the supernatant were mixed with a reaction medium containing thiobarbituric acid (TBA 0.8\%). Then, the samples were incubated at $95^{\circ} \mathrm{C}$ for one hour. The absorbance was measured at a wavelength of $532 \mathrm{~nm}$ in a spectrophotometer. The results were expressed in nmol MDA $/ 10^{6}$ cells.

The results of this experiment were analyzed with one-way analysis of variance followed by Tukey with GraphpadPrism 5.1 software. P-values < 0.05 were considered statistically significant.

\section{RESULTS}

The adipose tissue samples from both sites studied in this experiment were considered easily accessible and presented sufficient amounts of fat for the isolation of mesenchymal stromal stem cells. The method used for cell isolation and culture was satisfactory in this study and there was no interference, such as contamination or differentiation of cells, during the experiment. From the first to the sixth passage, the subcutaneous and omentum cells remained with fusiform morphology - similar to fibroblast cells - and adhered to the bottom of the culture flask (Fig.1A and B).

Regarding the viability and proliferation of cells in each passage, there was no statistically significant difference $(\mathrm{P}=0.0283)$ between the SC and OM group. However, it was observed that cells derived from subcutaneous tissue nee-

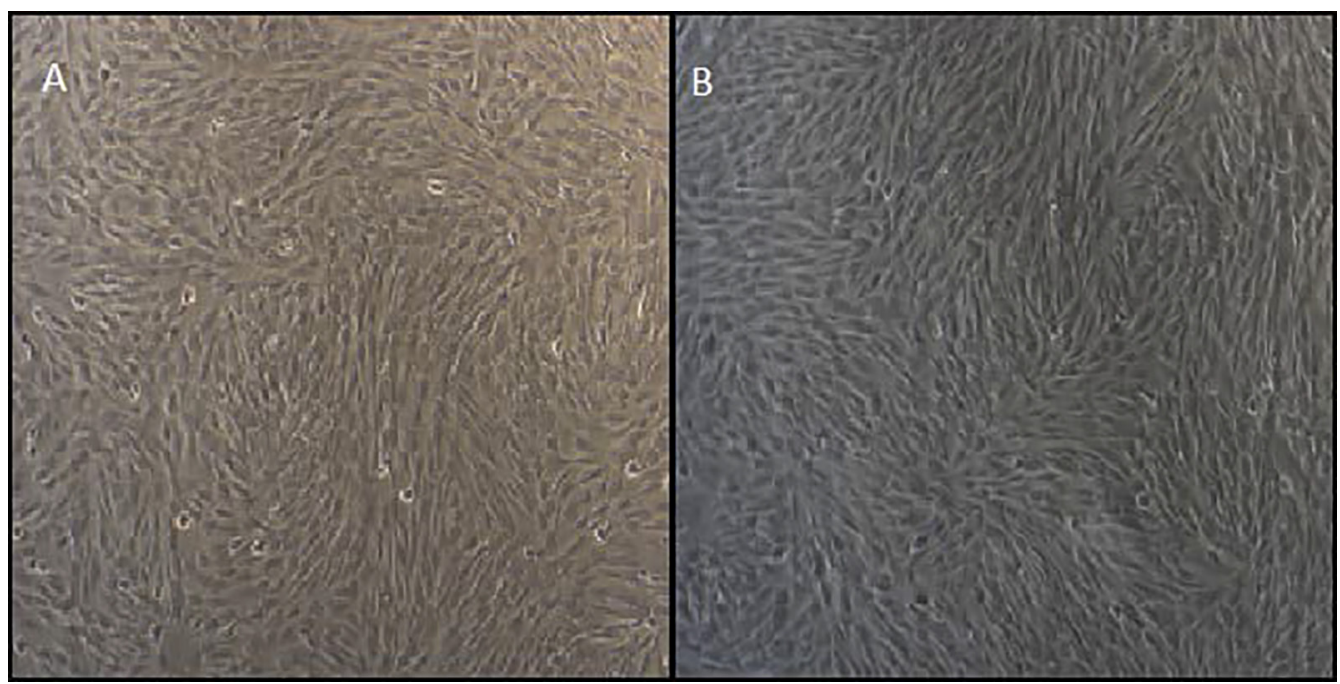

Fig.1. (A) Microscopic figure of cultured mesenchymal stromal stem cells from canine subcutaneous at sixth passage. Obj.20x. (B) Microscopic figure of cultured mesenchymal stromal stem cells from canine omentum at sixth passage. Obj.20x.

Table 1. Time (day) to reach $90 \%$ of cell confluence in culture cell flask $(75 \mathrm{~cm} 2)$, number of cells per $\mathrm{mL}$ and viability percentage of each passage $(P)$ of cultured mesenchymal stem cell from adipose tissue of canine subcutaneous and omentum

\begin{tabular}{cccc}
\hline Group & Proliferation & Viability & Time \\
\hline Subcutaneous & (P1) $2 \times 106$ & $95,6 \%$ & 7 days \\
& (P2) $2,2 \times 106$ & $96,4 \%$ & 6 days \\
(P3) $3 \times 106$ & $98,1 \%$ & 3 days \\
& (P4) $2,5 \times 106$ & $97 \%$ & 6 days \\
(P5) $2,2 \times 106$ & $97,8 \%$ & 7 days \\
Omentum & (P6) $2 \times 106$ & $96,3 \%$ & 5 days \\
& (P1) $5 \times 105$ & $95,6 \%$ & 7 days \\
& (P2) $8 \times 105$ & $96,2 \%$ & 13 days \\
& (P3) $1,5 \times 106$ & $98,9 \%$ & 5 days \\
& (P4) $1 \times 106$ & $96,2 \%$ & 5 days \\
& (P5) $1 \times 106$ & $97,5 \%$ & 7 days \\
(P6) $3 \times 106$ & $96,7 \%$ & 7 days
\end{tabular}

ded less time to reach a greater number of cells $/ \mathrm{ml}$ when compared with the omentum group, except for the third passage. The results are shown in Table 1.

It was possible to observe that the first passage presented the lowest rate of cell proliferation and viability percentage in both groups. The SC group reached its maximum cell number and viability in the third passage, with a slight decreased result in the subsequent passages. It is worth noting that it took 72 hours for the third passage to reach a $90 \%$ of cell confluence. The OM group reached its maximum cell proliferation in the last passage, but the best viability was found in the third passage. The shortest time ( 5 days) between passages in the OM group occurred in the passages number three and four.

The rate of reactive oxygen species (ROS) was determined by testing diclorofluoresceina diacetate (DCFH-DA), 
in which it was observed an increase of ROS in the first passage of SC and OM group. The fifth passage of SC group showed lower rate of ROS, whereas in the OM group it was in the sixth passage. There was a statistically significant difference between groups in the fifth and sixth passages for ROS rates. The results are shown in the Table 2.

Lipid peroxidation was determined by the rate of thiobarbituric acid reactive species (TBARS). The assay demonstrated higher levels of peroxidation in the first passage of the SC group. Conversely, the OM group presented a greater percentage of TBARS in the last passage. For subcutaneous cells, the third passage presented the least peroxidation levels, whereas in the omentum group this trend was observed in the forth passage. Additional data is presented in Table 3.

The percentage of free DNA present in each passage of the culture was evaluated by the DNA fragmentation with Picogreen dye assay. Free DNA has presented its lowest results in the first passage of the SC group and in the fifth passage of the OM, as presented in Table 4. The free DNA greatest percentage occurred in the third and first passage in the SC and OM group, respectively.

Table 2. Reactive oxygen species percentage meausered by 2-70-dichlorofluorescein diacetato (DCFH-DA) assay over six passages of cultured mesenchymal stem cells from adipose tissue of canine subcutaneous and omentum

\begin{tabular}{ccc}
\hline Passage & Subcutaneous & Omentum \\
\hline P1 & $94.44427 \mathrm{a}$ & $91.80975 \mathrm{a}$ \\
P2 & $80.90575 \mathrm{a}$ & $73.74637 \mathrm{a}$ \\
P3 & $88.25431 \mathrm{a}$ & $75.21389 \mathrm{a}$ \\
P4 & $87.45013 \mathrm{a}$ & $75.19928 \mathrm{a}$ \\
P5 & $46.58894 \mathrm{~b}$ & $87.93534 \mathrm{a}$ \\
P6 & $81.99699 \mathrm{a}$ & $5.727817 \mathrm{c}$
\end{tabular}

Table 3. Lipid peroxidation percentage measured by thiobarbituric acid reactive species (TBARS) over six passages in cultured mesenchymal stem cells from adipose tissue of canine subcutaneous and omentum

\begin{tabular}{ccc}
\hline Passage & Subcutaneous (\%) & Omentum (\%) \\
\hline P1 & $50.33436 \mathrm{a}$ & $34.99421 \mathrm{a}$ \\
P2 & $30.45267 \mathrm{a}$ & $36.58749 \mathrm{a}$ \\
P3 & $30.06687 \mathrm{a}$ & $42.4971 \mathrm{a}$ \\
P4 & $30.11831 \mathrm{a}$ & $33.31402 \mathrm{a}$ \\
P5 & $31.73868 \mathrm{a}$ & $40.23754 \mathrm{a}$ \\
P6 & $42.23251 \mathrm{a}$ & $88.29664 \mathrm{~b}$
\end{tabular}

Where "a" there is no statistically difference, "b" there is statistically difference.

Table 4. Free DNA percentage measured by DNA fragmentation through fluorimetric Picogreen over six passages in cultured mesenchymal stem cells from adipose tissue of canine subcutaneous and omentum

\begin{tabular}{ccc}
\hline Passage & Subcutaneous (\%) & Omentum (\%) \\
\hline P1 & $22.43864 \mathrm{a}$ & $81.9571 \mathrm{c}$ \\
P2 & $35.51861 \mathrm{a}$ & $71.08434 \mathrm{a}$ \\
P3 & $92,31987 \mathrm{~b}$ & $51.11666 \mathrm{a}$ \\
P4 & $40.30087 \mathrm{a}$ & $62.00411 \mathrm{a}$ \\
P5 & $33.37292 \mathrm{a}$ & $49.42698 \mathrm{a}$ \\
P6 & $32.03484 \mathrm{a}$ & $61.46048 \mathrm{a}$
\end{tabular}

Where "a" there is no statistically difference, "b" there is statistically difference.

\section{DISCUSSION}

The omentum is an intra-abdominal adipose membrane that actively participates in the repair of injured abdominal organs by promoting neovascularization, lymphatic drainage and enhancement of wound healing (Ruffini 1992). In recent years, the omentum has been studied as a source of mesenchymal stem cells and it is known that these cells are involved in the healing of internal organs and tissue (García-Gómez et al. 2005). In this study, the omentum proved to be a suitable source of stem cells in dogs. This result goes against the findings of Neupane et al. (2008) that did not succeed in the isolation of stem cell from omentum and inguinal fat. The disadvantage of using omentum to isolate stem cells is the need of celiotomy to obtain the material. In this case the samples were collected from a corpse, thus opening the abdominal cavity was not a challenge at present. Moreover, after the abdominal wall incision, the omentum fat was easily located and quickly removed.

Stem cells from subcutaneous adipose tissue are already well discussed in literature. The extraction of subcutaneous fat can be achieved by liposuction or lipectomy and, in both situations, the stem cells are able to be undifferentiated for long periods in culture and have high capacity of differentiation (Danoviz et al. 2011). However, Heimburg et al. (2004) found that subcutaneous fat liposuctioned showed a better performance when compared to those removed by excision. In this present experiment, the fat was excised with Metzembaum scissors from the abdominal middle line, and demonstrated a high proliferation capacity in all passages.

Additionally, there was no statistical difference between $\mathrm{OM}$ and SC group. The SC group presented a progressive increase in cell number, reaching its peak in the third passage with a mild reduction in the subsequent passages. This cell growth behavior was also found by Colleoni (2009) and Patrício et al. (2013), who studied the kinetics of mesenchymal stem cells growth of adipose tissue in horses and dogs, respectively. Similarly, Patrício et al. (2013) reported that the highest peak of proliferation also occurred in passage three. The OM group showed the same pattern of cell growth, despite having a reduced proliferation rate. However, during the sixth passage there was a considerable peak of cell proliferation for the OM group, which was not perceived in the SC group.

The viability rates found in both groups did not statistically differ and were considered highly viable in this experiment. The smallest viability percentage in this experiment was $95.6 \%$ in the first passage of SC and OM groups. This was also line with former results of Patrício et al. (2013), in which the lowest rate of viability found was $96 \%$ in the first two passages. Conversely, a previous study involving subcutaneous fat from rabbits reported viability rates close to $100 \%$ in the first passages, decreasing in the third and reaching the lowest levels in eighth (Treichel 2014).

It is noteworthy that the amount of cells and high viability rates do not necessarily mean a safe therapeutic choice. Equally important, oxidative stress has been linked to several diseases and genomic altered cells in culture (Halliwell 2007, Duailibi 2012 ). The assay of DCFH-DA performed in 
this paper suggests that the first passage of both groups presented higher rates of reactive oxygen species (ROS). However, in the subsequent passages the level of ROS did not vary significantly until the fifth passage of the SC and the sixth passage of OM group, which happened to be the lowest rate reported throughout the experiment. The authors correlate this simultaneous significant reduction of ROS in the last passage of the OM group with the highest peak of cell proliferation. This suggests that the low levels of free radicals may have influenced the increase of cells proliferation. This phenomenon did not occur in the SC group, but it is possible to argue that the decrease of ROS in SC group was not sufficient to promote a new peak of cell proliferation. Notice that the decreased level of ROS in the OM group was eight times higher than that observed in the SC group. In a similar study using adipose tissue from rabbits, the increase in ROS percentage was correlated with a lower percentage of cell viability (Treichel 2014). This relationship was also observed in the first passage of both groups in the present investigation, nonetheless it did not remain as a constant pattern throughout the passages.

When the lipid structures are damage by the action of free radicals, there is the ultimate formation of malondialdehyde (MDA) as a subproduct of polyunsaturated acids oxidation. The TBARS analysis identifies the presence of MDA and its increased levels are associated to damage in the cell membranes (Yang et al. 2008). At present, TBARS levels varied between groups. In the SC group the highest rate of lipid peroxidation occurred in the first passage, coinciding with the lowest percentage of viability and high level of reactive oxygen species. This happens due to an alteration in cell permeability caused when the membranes are damaged and, as a result, there is loss of selectivity, thus allowing input and output of nutrients and toxic molecule (Hershko 1989). In the following passages the percentage of lipid peroxidation varied slightly. The OM group presented higher TBARS levels, nevertheless, it was only in the last passage that it was noted a statistical difference when compared to SC group.

Furthermore, through analysis of data presented in Figure 1, where the percentage of free DNA was measured, it may be notice that lipid peroxidation relates to DNA levels. That is mainly because the presence of DNA outside the nucleus implied nuclear membrane damage (Caldecott 2008). At some points, it is also perceived a relationship between the high level of ROS and the presence of free DNA, as observed in the third passage of SC group and first pass of OM.

In this study, according to tests and assessment results the first and last passages are of particular interest in terms of viability, oxidative stress and cytotoxicity. Nikita et al. (2011) also showed similar results when evaluating the quality of mesenchymal cells from human bone marrow. The authors reported damaged cells in the initial and final stages of culture. Taking cell proliferation, viability, oxidative stress and cytotoxicity into account, the fifth passage of subcutaneous group displayed best results for those variables. In the OM group the best observed passages considering the mentioned variables were the fourth and fifth. In contrast with our results another study, in which the au- thors evaluated oxidative and DNA damages of stem cells from canine dental pulp, the first passages showed lower oxidative stress and genomic damage. From the forth passage, the levels of ROS and DNA damage began to increase considerably (Aramburú Junior 2013). This variation in results may be due to different methods of cultivation and tissue origin, suggesting that each research group should evaluate the quality of their own cultivated cells.

The data obtained here may help researchers in future studies proposed to understand the behavior of mesenchymal stromal stem cells from adipose tissue. This also may apply to conduct veterinarians who want to explore the regenerative potential of stem cells as therapy in clinical practice. Given the importance of discussing the positive and negative factors involved in cell therapy, the authors suggest that more research must be directed to the stability of cultured stem cells before clinical use. Amongst the methodological limitations related to the present study was lack of investigation of some biomarkers of viability, genetic mutation and cellular senescence.

It is important to note that, samples were collected of only one dog in order to avoid variables such as age, health and nutritional status, which may lead to variations during the harvesting of mesenchymal stem cells and oxidative stress levels. The accumulation of senescent cells in aged animals may result in decrease of cells' replicative life in vitro due to the shortening of telomeres. Besides that, the regulatory mechanisms of free radical production become ineffective over time (Teixeira \& Guariento 2010). Nevertheless, to obtain sufficient samples to statistics analysis, all the tests were performed in quadruplicate.

\section{CONCLUSIONS}

Based on the methodology in which the experiment was conducted and the final data were obtained, it can be concluded that the subcutaneous adipose tissue and the omentum from dogs are a viable source of mesenchymal stem cells, even after 30 minutes postmortem with no significant differences between these tissues.

The first and last passage should be avoided in the treatment of clinical diseases, given the large exposure of these cells to stress and oxidative damage.

\section{REFERENCES}

Aramburú Junior J.S. 2013. Isolamento e análise de danos genômicos de células-tronco da polpa dentária de cães. Dissertação de Mestrado, Curso de Pós-Graduação em Medicina Veterinária, Universidade Federal de Santa Maria, RS. 93p.

Bonventre J.V. \& Yang L. 2011. Cellular pathophysiology of ischemic acute kidney injury. J. Clin. Invest. 121:4210-4221.

Caldecott K.W. 2008. Single-strand break repair and genetic disease. Nature Revs Genetics 9:619-631.

Colleoni S., Bottani E., Tessaro I., Mari G., Merlo B., Romagnoli N., Spadari A., Galli C. \& Lazzari G. 2009. Isolation, growth and differentiation of equine mesenchymal stem cells: effect of donor, source, amount of tissue and supplementation with basic fibroblast growth factor. Vet. Res. Commun. 33:811-821.

Danoviz M.E., Bassaneza V., Nakamuta J.S., Santos-junior G.R., Saint-clair D. \& Bajgelman M.C. 2011. Adipose tissue-derived stem cell from humans and mice differ in prolifarative capacity and genome stability in longterm cultures. Stem Cell Dev. 20:4:661-670. 
Dröge W. 2002. Free radicals in the physiological control of cell function. Physiol. Revs 82:47-95.

Duailibi M.T. 2012. Cytogenetic instability of dental pulp stem cell lines. J. Molec. Histol. 43:89-94.

Fadel L., Viana B.R., Feitosa M.L.T., Ercolin A.C.M., Roballo C.S., Casals B., Piere N.C.G., Meirelles F.V., Martins D.S., Miglino M.A. \& Ambrósio C.E. 2011. Protocols for obtainment and isolation of two mesenchymal stem cell sources in sheep. Acta Cir. Bras. 26:4:267-273.

Fortier L.A. 2005. Stem cells: classifications, controversies, and clinical applications. Vet. Surgery 34:415-423.

Furlani D. 2009. A transformed cell population derived from cultured mesenchymal stem cells has no functional effect after transplantation into the injured heart. Cell Transplant. 18:319-331.

García-Gómez I., Goldsmith H., Angulo J., Prados A., López-Hervás P., Cuevas B., Dujovny M. \& Cuevas P. 2005. Angiogenic capacity of human mental stem cells. Neurol. Res. 27:807-811.

Halliwell B. 2007. Oxidative stress and cancer: have we moved forward? Biochem. J. 401:1-11.

Heimburg D.V., Hemmricha K. \& Haydarlioglua S. 2004. Comparison of viable cell yield from excised versus aspirated adipose tissue. Cells Tissues Organs 178:87-92.

Hershko C. 1989. Mechanism of iron toxicity and its possible role in red cell membrane damage. Seminars in Hematology 26:277-285.

Kern S., Eichler H. \& Stoeve J. 2006. Comparative analysis of mesenchymal stem cells from bone marrow, umbilical cord blood, or adipose tissue. Stem Cells 24:1294-1301.

Neupane M., Chang C.C. \& Kiupel M. 2008. Isolation and characterization of canine adipose-derived mesenchymal stem cell. Tissue Eng. 14:1007-1015.

Nikita V.A., Chausheva A.I., Zhanataev A.K., Osipova E.Y., Durnev A.D. \& Bochkov N.P. 2011. Assessment of DNA damage in human bone marrow cells and multipotent mesenchymal stromal cells. Bull. Exp. Biol. Med. 151:550-552.
Patrício L.F.L., Rebelatto C.L.K., Brofman P.R.S., Maciel B.B., Beltrame O.C., Britto H.F.V. \& Locatelli-Dittrich R. 2013. Isolamento e caracterização de células mesenquimais do tecido adiposo de cães. Arq. Bras. Med. Vet. Zootec. 65:946-954.

Pujalté I., Passagne I., Brouillaud B., Tréguer M., Durand E., Ohayon-Courtés C. \& L'Azou B. 2011. Cytotoxicity and oxidative stress induced by different metallic nanoparticles on human kidney cells. Particle and Fibre Toxicology 8:1-16.

Riley T., Sontag E., Chen P.P. \& Levine A. 2008. Transcriptional control of human p53-regulated genes. Nature Revs Molec. Cell Biol. 9:402-412.

Ruffini E. 1992. Surgical applications of the greater omentum: a critical review of the literature. PanMinerva Med. 34:135-140.

Sareen D. 2009. Chromossome 7 and 19 trisomy in cultured human neural progenitor cells. PloS ONE 29:4:1-33.

Teixeira I.N.D.O. \& Guariento M.E. 2010. Biologia do envelhecimento: teorias, mecanismos e perspectivas. Ciênc. Saúde Coletiva 15(6):28452857.

Treichel T.E. 2014. Contribuições para o uso de células estromais mesenquimais no reparo de feridas cutâneas e no transplante de pele em coelhos. Tese de Doutorado, Curso de Pós-Graduação em Medicina Veterinária, Universidade Federal de Santa Maria, RS. 93p.

Thomson J.A., Itskovitz-Eldor J., Shapiro S.S., Waknitz M.A., Swiergiel J., Marshall V.S. \& Jones J.M. 2008. Embryonic stem cell lines derived from human blastocysts. Science 282:1145-1147.

Tuan R.S., Boland G. \& Tuli R. 2003. Adult mesenchymal stem cells and cell-based tissue engineering. Arthritis Res. Ther. 5:32-45.

Williams K.J. 2008. Isolation and characterization of porcine adipose tissue-derived adult stem cells. Cells Tissues Organs 188:251-258.

Yang R.L., Shi Y.H., Hao G., Li W. \& Le G.W. 2008. Increasing in oxidative stress with progressive hyperlipidemia in human: relation between malondiladeyde and atherogenic index. J. Clin. Biochem. Nutr. 43:154158. 